\title{
Consequences of Glyphosate Contamination and its Remediation through Microbial and Mineral Sources
}

\author{
Qammar Farooq $^{1}$, Aqarab Husnain Gondal ${ }^{\text {* }}$, Humaira Ramzan ${ }^{4}$, Abu Bakar Ijaz ${ }^{1}$, \\ Asma Zafar ${ }^{1}$, Haroon Ilahi ${ }^{3}$, Muhammad Zohaib Aslam, Muhammad Danish Toor ${ }^{2}$, \\ Anam Sadaf ${ }^{4}$ and Muneeb Ur Rehman ${ }^{1}$ \\ ${ }^{1}$ Institute of Soil and Environmental Sciences, University of Agriculture, \\ Faisalabad 38040, Pakistan \\ ${ }^{2}$ European University of Lefke, Institute of Graduate Studies and Research, Department of \\ Environmental Sciences Northern Cyprus TR-10 Mersin Turkey \\ ${ }^{3}$ Department of Agriculture, University of Sawabi, Sawabi, Pakistan \\ ${ }^{4}$ Department of Agriculture, University of Sargodha, Sargodha, Punjab, Pakistan \\ *Corresponding author
}

\section{A B S T R A C T}

K e y w o r d s
Glyphosate,
Consequences,
Remediation
measures,
Microbes, Nitrogen,
plant growth, yield

\section{Introduction}

Organophosphates (OPs) are the most important pesticides because they provide protection to the plants from weeds and pests habitats, as stated above.
Glyphosate is a non-selective herbicide that is commonly used to combat a wide range of annual and perennial weeds. However, its widespread use has negative consequences for human beings and for the climate change. Aside from that, it has an effect on marine organisms, microbial biota in soil, which leads to a lack of soil fertility, and eventually reduces plant growth and yield, all of which has an impact on the food chain. Various methods have been used to eliminate glyphosate from polluted environments, but the most eco-friendly and cost-effective alternative is microbial degradation and the use of nitrogen, either singly or in combination with organic sources. Microbes release basic elements in the soil by their enzymatic processes, and they play an important role in improving plant growth and phytoremediation capacity by lowering the total toxicity of a pollutant to plants. Furthermore, dehydrogenase and urease processes, which are known to be the most critical measures of overall microbial development, are greatly influenced by nitrogen fertilizers. Hence, the effect of glyphosate should be analyzed in order to establish a conservation and management strategy to mitigate glyphosate toxicity of aquatic ecosystems, plant growth, and 
and aquatic system (Walpola et al., 2007). Glyphosate is also used to control algal blooms and noxious aquatic weeds (Siemering et al., 2008). Besides this, widespread usage of glyphosate in agriculture is increased after the initiation of genetically resistant (GR) crops (Woodburn, 2000) such as maize, canola, sugar beet and soybean (Duke, 2011). Glyphosate is used in agriculture and could enhance the maize yield by $19 \%$ (Masthan, 1989). Overall loss in crops yield due to weeds, pests and other diseases becomes double without usage of pesticides (FAO, 2017). In previous years, glyphosate use becomes dominant than other OPs products (Lipok et al., 2008).

The frequent use of glyphosate badly affects the environment and human health. After the application of glyphosate, it remains persistent in soil and environment (Ellis and Griffin, 2002; Wang et al., 2016). Half-life of glyphosate in soil may reach to 174 days (Vencill, 2002). Glyphosate excessive presence in soil leads to increase the glyphosate level in GR crops (Cerdeira et al., 2010). The increased uptake and accumulation of glyphosate in consumable part of the crop negatively affects the human health and causes cancer in any part of the human body (prostate, lungs and liver) and disturbs the nervous system and reproduction in animals (Xu et al., 2019). Additionally, most of the Ops including glyphosate are mobile in nature and causes contamination of groundwater (Atterby et al., 2002). Various strategies are used to remove glyphosate from the contaminated environments and mitigate the effect of glyphosate on the soil-plant systems shown in Figure 1.

\section{Effects on water bodies}

Glyphosate is a weed-controlling agrochemical commonly used in agriculture. Glyphosate, on the other hand, spreads to water sources by run-off, spray drift and leaching, possibly harming non-target biota and as well as aquatic life (Ruiz-Toledo et al., 2014). Furthermore, several experiments have shown the negative impact of glyphosate on amphibians, fish, mammals, and birds (Relyea 2005). Glyphosate kills the macrophyte population in the marine system, and acts as a microhabitat for phytoplanktonic, zooplanktonic and periphytic communities and these results in top-down dominance of planktonic populations, influencing fish shelter and feeding. Fish may be exposed to lyphosate and formulation compounds by their gills and digestive tracts after ingesting infected food or water (Annett et al., 2017). Glyphosate is ingested and spread across the body by the blood circuit, touching many tissues until within the species. GBHs have a variety of effects on fish, affecting a variety of organs as well as molecular stages (Annett et al., 2017).In the liver, glyphosate induces vacuolization and nuclear pyknoses; in the kidney, tests show Bowman capsule dilatation and hyaline decline accumulation in tubular cells; and in the gills, glyphosate causes hyperplasia, lamellar fusion, and aneurism (Ayoola et al., 2017).

\section{Effects in soil properties}

Glyphosate use of farm land has an effect on the soil and seed bed, as well as extreme deforestation and other forms of land depletion (Teamti and Tesfay, 2016). The glyphosate concentration up to some extent in soil disrupts the soil properties including soil texture, cation exchange capacity, soil bulk density, available phosphorus, total nitrogen and soil moisture contents (Saraswathi, 2019).However, some tests have found that there is a risk of glyphosate leaching into deeper soil layers, where it could end up in land and surface waters in some cases. Sorption is affected by a variety of factors, including mineral quality and form, $\mathrm{pH}$ that is 
important factor of soil health determination (Gondal et al., 2021a), soil redox conditions, and phosphate content (that can compete with glyphosate for sorption sites)and potentially organic matter in the soil. Furthermore, micro nutrients (Zn) and various other macro nutrients availability may become stunted due to contamination (Gondal et al., 2021b; Bakar Ijaz et al., 2021). Rainfall and bad soil conditions will increase the risk of glyphosate evaporation from soils.

\section{Effects on plant growth}

As a result, glyphosate residues in soils are likely to be exposed to seed-propagated crops with minimal endosperms as an energy source after imbibition at the start of seed germination. Potato sprouts, on the other hand, are more self-sufficient, feeding mainly on the tuber, while seedlings have little energy storage in the cotyledon. In addition, it increases the pathogen and pests attack on crop germination stage (Martinez et al., 2018).

In glyphosate contaminated soils, oat, faba bean, and turnip rape emerging percentage was greatly delayed. Furthermore, previous studies showed significantly reduction in yield and yield components due excessive dosage of glyphosate polluted sites. It also reduce the physiological parameters such as indole acetic acid concentration, proline contents, chlorophyll $\mathrm{a}$ and $\mathrm{b}$, amino acids and other essential components from the yield as well as from plant parts (Fernández-Escalada, 2019).

\section{Effects on human and animal health}

Thus people are using higher concentrated glyphosate contaminated yield and it leads to different diseases in humans as well as in animals. Glyphosate have been shown in recent studies to have the potential to harm animal reproduction by disrupting key regulatory enzymes in androgen synthesis, altering serum levels of testosterone, estrogen, damaging reproductive tissues, and impairing game to genesis (Jarrell et al., 2020).

\section{Remediation measures}

Various strategies are used to remove glyphosate from the contaminated environments and mitigate the effect of glyphosate on the soil-plant system. Among biological approaches, phytoremediation and microbial degradation of glyphosate are suitable options due to their eco-friendly and cost-effective nature (Prihastuti et al., 2014).

\section{Microbial approaches}

Microbes have ability to remove glyphosate from soil and improve soil productivity as well as sustainability. Moreover, the microbes release different enzymes from their body to degrade the glyphosate compounds to get energy source in the form of phosphorus, nitrogen and carbon (Zulfiqar and Yasmin, 2020). After decay, decomposition products lead to improve the soil fertility status and plant growth. The products obtained from glyphosate degradation in first pathway are carbon dioxide, methanol, ammonia and phosphate (Araujo et al., 2003) and in second pathway are amino acids including cysteine, glycine, methionine, serine and histidine (Pipke et al., 1987). The obtained products may increase the growth of plants in glyphosate-contaminated soil. Additionally, the previous studies revealed that soil microbes have great tolerance against these herbicides (Lane et al., 2012). 
Fig.1 Effect of glyphosate on soil-air-plant system

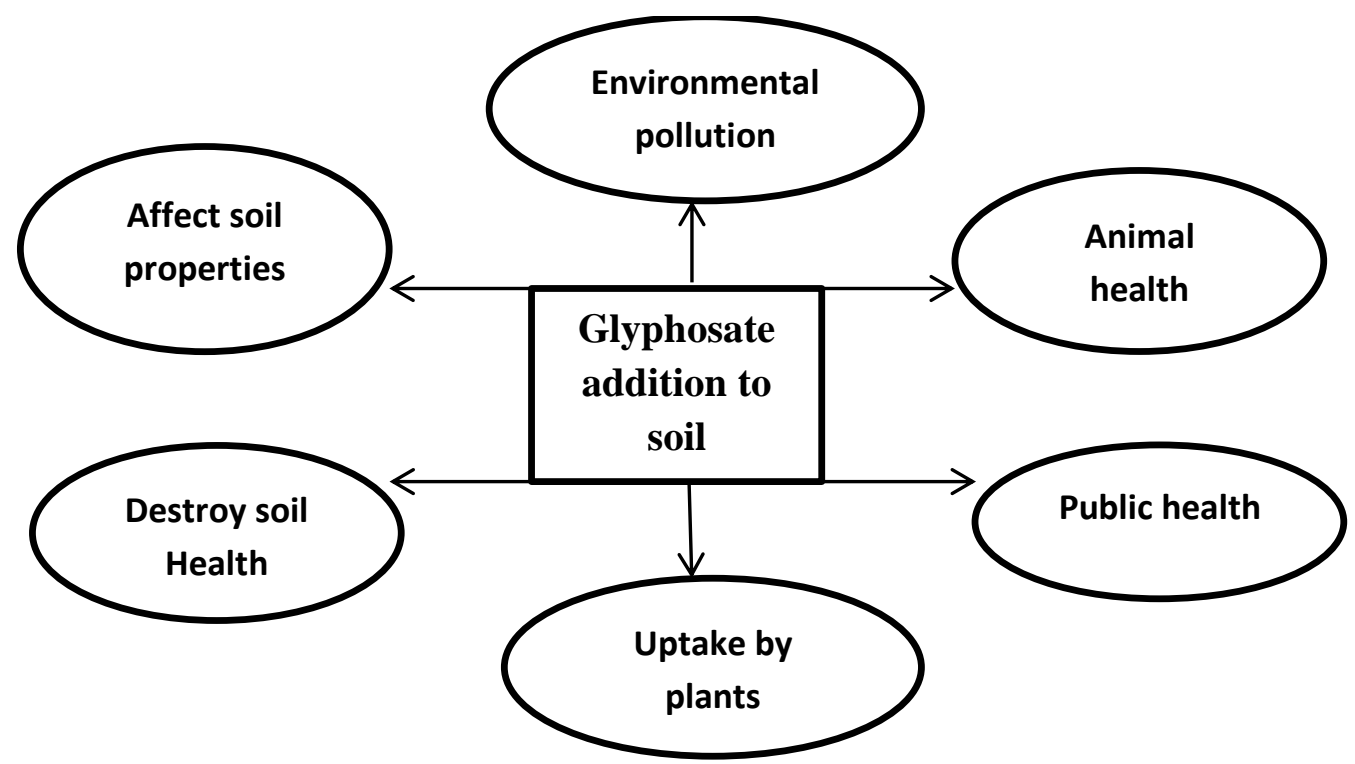

Source: (Gondal et al., 2021c)

\section{Nitrogen sources}

Nitrogen is one of the most essential elements for plant growth (Stefanovic et al., 2010). Glyphosate application with nitrogen fertilizer is increased worldwide in order to mitigate the negative impacts of pollutants such as glyphosate on environment and growth of plants (Nivelle et al., 2017).

The metabolic activities such as nutrients availability, nitrate contents, phosphate contents, alkaline phosphatase and urease enzymes activities and nitrification process are enhanced after application of glyphosate with nitrogen fertilizer (Nivelle et al., 2017).

In addition, nitrogen fertilizers significantly influence the dehydrogenase and urease activities, which are considered as most important indicators of total microbial activity (Dick et al., 1992).

In general, microbes use two pathways to decompose the glyphosate compound namely glyoxylate and aminomethylphosphonic acid (Schuette, 1998).

\section{Phosphorus sources}

The presence of phosphate greatly reduced glyphosate adsorption to soils by vying with glyphosate for soil adsorption locations. Meanwhile, on the two transient charge soils, the effects of phosphate on glyphosate adsorption were more important than on the permanent charge soil. Previous studies revealed significantly enhancement in crop growth and yield due to application of phosphorus in glyphosate contaminated soils. Glyphosate inhibits the shikmate pathway and negatively effects on photosynthesis process (Siehl and Roe, 1997). As phosphate and glyphosate compete for adsorption sites in the soil so, it can be uptake by the plant (Denis and Delrot, 1993). Glyphosate can uptake and translocate in soil and can remediate soil through phytoremediation. Available phosphorus can enhance the physiochemical properties of plants. Gomes et al., 2016 concluded that willow plant phytoremediation increase by the addition of mineral nutrient (Gomes et al., 2016). Pakistan imports a substantial volume of pesticides per year, including herbicides, insecticides, and 
fungicides. It is undeniable that improper and inappropriate application of pesticides, especially glyphosate, has adverse effects on human health and the climate, while determining the true nature of these effects is challenging. There is currently no agreement on a particular mechanism of glyphosate toxicity; it is most likely made up of many mechanisms that vary based on the formula and organisms. As a result, it's still necessary to figure out how glyphosate toxicity works in a variety of organisms. Several scientists use various approaches to remove glyphosate and mitigate its toxic effects on plants; however, limited studies are available on the use of microbes in combination with different level of $\mathrm{N}$ fertilizers for improving maize growth and removal of glyphosate from soil. Therefore, the aim of this study is to evaluate the effects of a microbial consortium and different level of nitrogen on remediation of glyphosate and growth of maize in glyphosatepolluted soil. It is important to encourage organic farming activities that use biopesticides or biological agents to combat weeds rather than herbicides to minimize the use of glyphosate.

\section{References}

Annett R, Habibi H R, Hontela A. Impact of glyphosate and glyphosate-based herbicides on the fresh water environment. Journal of Applied Toxicology. 2014;34(5):458-479.

Araujo, A. D., R. T. R. Monteiro, R. B. Abarkeli. 2003. Effect of glyphosate on the microbial activity of two Brazilian soils. Chemosphere. 52(2): 799-804.

Atterby, H., N. Smith, Q. Chaudhry, D. Stead. 2002. Exploiting microbes and plants to clean up pesticide-contaminated environments. Pesticide Outlook. 13(1): 9-13.

Ayoola S O. Histopathological effects of glyphosate on juvenile African catfish (Clariasgariepinus). American Journal of Environmental Science. 2008;4(3):362-367.

Bakar Ijaz, S S., Bisma Imran, C H., Taufiq Nawaz, S., Haider, I A A., Dua-e-Zainab, B
R., Qasim, M.,... \& Rehman, M U. (2021). Alleviation of zinc deficiency from humans through plants by organic sources: A Powerful Tonic. IJAR, 7(4), 240-243.

Cerdeira, A. L., S. Duke. 2010. Effect of glyphosate resistant crop cultivation on soil and water quality. Brazilian Agricultural Research. 1(1): 16-24.

Dick, W. A., M. A. Tabatabai. 1992. Significance and potential use of soil enzymes. A meeting on soil microbial ecology and application and environmental management. Marcel Dekker, New York. 99-110.

Duke, S.O. 2011. Glyphosate degradation in glyphosate-resistant and-susceptible crops and weeds. Journal of Agricultural and Food Chemistry. 59(11): 5835-5841.

Ellis, J. M., J. L. Griffin. 2002. Soybean and cotton response to simulated drift of glyphosate and glufosinate. Weed Technology. 16: 580-586.

FAO. 2017. Trade and market division, food outlook: oilseeds. Oils and Meals. 1-16.

Fernández-Escalada, M., Zulet-González, A., GilMonreal, M., Royuela, M., \& Zabalza, A. (2019). Physiological performance of glyphosate and imazamox mixtures on Amaranthuspalmeri sensitive and resistant to glyphosate. Scientific reports, 9(1), 1-14.

Gondal A. H, Shamal S K, Hasnain U, Ananta G M, Asma Z. Glyphosate Remediation through Microbes and Mineral Sources: A Short Communication. Ann Rev Resear. (2021c); 6(4): 55-61.

Gondal, A H., Zafar, A., Zainab, D., Toor, M D., Sohail, S., Ameen, S., Ijaz, A B., Imran BCh, Hussain, I., Haider, S., Ahmad, I. A., Rehman, B., \& Younas, N. (2021a). A Detailed Review Study of Zinc Involvement in Animal, Plant and Human Nutrition, Ind. J. Pure App. Biosci. 9(2), 262-271.

Gondal, H A., Hussain, I. Ijaz, B A. Zafar, A. Ch, I B., Zafar, H. Sohail, D M. Niazi, H. Touseef, M. Khan, A A. Tariq, M. (2021b). Influence of Soil $\mathrm{Ph}$ and Microbes on Mineral Solubility and Plant Nutrition: A Review. International Journal of Agriculture and Biological Sciences. 5(1):71-81.

Jarrell, Z. R., Ahammad, M. U., \& Benson, A. P. (2020). Glyphosate-based herbicide formulations and reproductive toxicity in 
animals. Veterinary and Animal Science, 100126.

Lane, M., N. Lorenz, J. Saxena, C. Ramsier, R. P. Dick. 2012. Microbial activity, community structure and potassium dynamics in rhizosphere soil of soybean plants treated with glyphosate. International Journal of Soil Biology. 55: 153-159.

Lipok J, D. Wieczorek, M. S. Jewgin, P. Kafarski. 2009. Prospects of in vivo 31P NMR method in glyphosate degradation studies in whole cell system. Enzyme and Microbial Technology. 44: 11-16.

Martinez, D. A., Loening, U. E. \& Graham, M. C. Impacts of glyphosate-based herbicides on disease resistance and health of crops: a review. Environ. Sci. Europe 30, 2, https://doi.org/10.1186/s12302-018-0131-7 (2018).

Nivelle, E., J. Verzeaux, A. Chabot, D. Roger, F. Spicher, J. Lacoux. 2017. Does nitrogen fertilization history affects short-term microbial responses and chemical properties of soils submitted to different glyphosate concentrations? PLOS ONE. 12(5).

Pipke, R., N. Amrhein, G. S. Jacob, J. Schaefer, G. M. Kishore. 1987. Metabolism of glyphosate in an Arthrobacter species. European Journal of Biochemistry. 165(2): 267-273.

Prihastuti, T. 2014. Commercialization prospects of microbial and Soil microbial formulation in Indonesia in agriculture. International Journal of Soil and Crop Sciences. 2: 46-53.

Ruiz-Toledo, J., Castro, R., Rivero-Pérez, N., Bello-Mendoza, R., \& Sánchez, D. (2014). Occurrence of glyphosate in water bodies derived from intensive agriculture in a tropical region of southern Mexico. Bulletin of environmental contamination and toxicology, 93(3), 289-293.

Saraswathi, M. (2019). Impact of Glyphosate on Agricultural Soil Quality in SinanaWoreda,
South Eastern Ethopia. International Journal of African and Asian Studies, 59, 8-17.

Schuette, J. 1988. Environmental fate of glyphosate. Environmental Monitoring and Pest Management. 1(1): 1-13.

Siemering, G. S., J. D. Hayworth, B. K. Greenfield. 2008. Assessment of potential aquatic herbicide impacts in California aquatic ecosystems. Archives of Environmental Contamination and Toxicology. 55(3): 415-431.

Stefanovic, I., S. Prokic, L. Rankovic. 2010. Motivational and success factors of entrepreneurs: the evidence from a developing country. Proceeding of the Faculty of Economics in Rijeka. 28(2): 251269.

Teamti, T., \& Tesfay, A. (2016). Farmers' perception on glyphosate application in conservation agriculture system of Northern Ethiopia Journal International of African and Asian Studies, 17 "Vol".:32-34.

Vencill, W. K. 2002. Herbicide handbook (No. Ed. 8). Weed Science Society of America.

Walpola, D. C., S. D. Wanniarachchi, J. A. Liyanage. 2007. Responses of soil microbial biomass carbon to the herbicides propanil and glyphosate. Journal Agricultural Sciences. 3: 122-130.

Xu, J., S. Smith, G. Smith, W. Wang, Y. Li. 2019. Glyphosate contamination in grains and foods. Food Control. 106.

Yang, Q., J. Wang, W. Zhang, F. Liu, X. Yue, Y. Liu, M. L. Yang, Z. J. Wang. 2017. Interface engineering of metal organic framework on graphene oxide with enhanced adsorption capacity for organophosphorus pesticide. Chemical Engineering. 313: 19-26.

Zulfiqar, A., A. Yasmin 2020. Microbiological aspects of pesticide remediation. Bioremediation and Biotechnology. 3: 139171.

\section{How to cite this article:}

Qammar Farooq, Aqarab Husnain Gondal, Humaira Ramzan, Abu Bakar Ijaz, Asma Zafar, Haroon Ilahi, Muhammad Zohaib Aslam, Muhammad Danish Toor, Anam Sadaf and Muneeb Ur Rehman. 2021. Consequences of Glyphosate Contamination and its Remediation through Microbial and Mineral Sources. Int.J.Curr.Microbiol.App.Sci. 10(06): 152-157.

doi: https://doi.org/10.20546/ijcmas.2021.1006.016 